\title{
'A Not-so-simple Story from My Life': Using Auto-ethnography and Creative Writing to Re-frame the Heteronormative Narratives of School Life
}

\author{
Angela Rickard*
}

Education Department, Maynooth University, Maynooth, Ireland

\begin{abstract}
Reflecting on my experience as a teacher and a lesbian in a second-level school in Ireland in the early 1990s, I use an auto-ethnographic approach first to explore some of the ways dominant narratives can silence, constrain and marginalise some people. Projecting forward to an imagined future, I draw on creative writing to 're-frame' how identity could be represented and experienced. While it is noted that context, attitudes and experiences have changed for the better in the intervening decades, legislative frames still hold fast, and heteronormativity continues to curb expressions of difference. Adopting a creatively disruptive style and format, I hope to provide a glimpse of a new normal in schools where more positive and less alienating experiences are imaginable ... for everyone.
\end{abstract}

Keywords: auto-ethnography; narrative; education; Ireland; heteronormativity

\section{Introduction}

The story presented below explores an incident from my life as a means to uncover ways in which available narratives can silence, constrain and marginalise some people. Framing myself within a creative non-fiction piece (Episode 1) at the start, and in an entirely imagined encounter (Episode 2) at the end, provides me with both a device and a metaphor with which to decipher how 'reality' is inscribed:

[t]he frame does not simply exhibit reality, but actively participates in a strategy of containment, selectively producing and enforcing what will count as reality. (Butler 2011, xiii)

Writing and reflecting on auto-ethnographic inquiry has been, paradoxically, as troubling and constraining for me as it has been liberating and creative. Trialling (in more ways than one) self-scrutiny has pushed me to respond to complex questions of re-presentation, self-care and ethics. Not only has it prompted a consideration of the ways we shape our stories and are shaped by them but the process, as well as the puns, playfulness with content, form and typography of written language, have propelled me to yet more troublesome encounters with powerful narratives.

\section{Episode 1}

A short story where the narrator looks back in time and finds herself wanting As I walk into the second-floor classroom I do a quick scan. Anyone I know? New people? I nod, smile.

\footnotetext{
*Email: Angela.Rickard@nuim.ie
} 
- Renée! Hiya. Good to see you.

I take a seat between Renée and a woman I haven't met before.

- Hi. I'm Angela.

- Hello. Denise.

We chat for while before the class begins: Renée, Denise and I.

After a few first-day formalities the tutor sets us to work on a writing task for this unit on auto-ethnography.

'Very simple', he says, 'I'd like you to tell a story from your past. Not your life's story, ok? Just a simple story from your life. Tell it to the person beside you. Take notes as you listen and reflect it back. And vice versa. Have a think about it for a few minutes and decide who'll start.'

A simple story, he said. I can hear the familiar sparring voices in my head telling me that I'm crap at telling stories: too earnest. Or maybe I just don't have enough practice. Yeah! That's it! Always holding back. Well yes, but with good reason! I remind myself. We're wasting time now ... a story? A feckin' story? Come on, think of something! ... something that isn't bloody depressing, let's have one with a bit of entertainment value, can we? A good story.

These thoughts are not getting me very far, I should be thinking through a real event from my past, not arguing with myself about my lousy storytelling skills or my penchant for the morose. But as I turn to Denise to begin this exercise, a story from my past does actually come to mind. Great! I won't worry about the wording: I know what happened. I'm sure some of the detail will come back to me as we go along, even if it was a long time ago. I forget to worry about the entertainment value. Now, I just want to tell this story that has suddenly become utterly compelling to me for some reason. I haven't thought about this incident in - what? - 20 years? And now it has just popped into my head, just like that! Strange.

Deep breath, don't introduce it, I say to myself. Just start and let it speak for itself, if that's possible. I'm conscious that I feel comfortable enough with Denise to relate my story. And I amuse myself with the thought that I'll just 'come out' with it.

I used to be a secondary school teacher in a middle-class convent school in Ireland. One day, during a break, maybe I'm correcting copies or preparing for my next class I am alone in any case - I am approached by three or four Transition Year girls.

- Miss Rickard? Sorry to interrupt you, Miss. We'd like to ask you something.

- Ok, Clodagh, I say, putting down my pen. What's on your mind?

Clodagh is holding an envelope in her hand and she and the other girls look nervous for some reason.

- You see, Miss, we have this great idea for a film we're doing for our media production module. It's for our TY [Transition Year] Art class. We'd love it if you would play a part in it.

- Play a part? As in ... act?

- Yeah Miss, we think you'd be great! One of the other girls chips in.

- Ah girls, I'm flattered but I'm not really one for the limelight!

Clodagh insists: 
- No, but Miss you'd be brilliant. We've written you a formal invitation. Mrs. D. wants us to be very professional, like. I'm the producer. Actually, we all have different jobs. We've explained the scenario in this letter for you.

She hands me the envelope that she's been holding just as the bell rings for the next class.

- All right girls. I'll think about it.

- Ah thanks, Miss. You're great. You'll be brilliant in it!

- We'll make you famous, Miss!

- Go on now: I only said I'd think about it!

The girls leave and I open the envelope.

\section{Dear Miss Rickard,}

I am writing to you on behalf of our TY media production team. We plan to make a short film about bullying and we would like you to play the part of the English Teacher. It's the story of a girl who is being bullied by other girls in her class. She has no friends and is very isolated and sad. Only her English teacher notices her at all and she is the only person the girl talks to. But the girl is too afraid to tell her about the bullying.

In the end the girl can't stand it anymore and she takes her own life. The last scene shows you at the girl's funeral. When all the other mourners have left the graveyard the closing scene is of you, tearfully, throwing a red rose onto the girl's coffin.

We think this is a very moving story and we hope that you will accept our invitation to participate in our project.

Yours sincerely,

Clodagh

I put the letter down and find that I have a sick feeling in my stomach. A red rose? All I can see is 'inappropriate teacher-pupil relationship' written all over this. A headline flashes: 'Lesbo teacher mourns bullied girl' No way Mrs. D. I-Don't-Think-So! Professional letter or no professional letter: I wasn't born yesterday!

For a moment, I wonder if the girls have any idea of the hidden agenda here, probably not. But there is no doubt in my mind but there's more to this story than the 'Sympathetic-teacher' 'Only-one-who-understands' scenario that Mrs. D. has conjured up. There's another plot thickening here: of that I am sure.

However, to keep my paranoia in check I decide to talk to the one teacher on the staff I am out to. K. has known me since I was a pupil in this school myself and she knows Mrs. D. very well too, having worked with her for decades at this stage.

At lunchtime the next day I ask $\mathrm{K}$. to come with me for a walk around the school grounds and I tell her about the letter and the girls' project. Should I accept? I'm conscious that despite my misgivings about Mrs. D., the girls do seem genuinely committed to the project and have already gone to so much trouble. I honestly think they'll be gutted if I refuse.

- What do you think K.? Am I reading too much into it?

- Angela, let's put it this way, if this film is made you won't have any say as to how it is read or by whom.

- Very true! 
- It looks innocent enough on one level. And you're right: I don't think the girls are aware of any ulterior motive. But I do think that Mrs. D. is up to her usual mischief. In fairness though, it's not out of badness: she's an artist and she just likes to be the agent provocateur.

- Yeah. Well, that's what I was afraid of. On the other hand, I was also thinking maybe it might be a good thing to do. You know, get the whole thing out in the open once and for all, what the hell? Feck this double life! Why not let this story get told and face the music afterwards?

- But Angela, this isn't your story and you can't be sure how it will be seen, or what the fallout will be afterwards. The sinister innuendo? The thinly veiled contempt? Do you really think you'd cope with that? I think you are being set up, quite frankly.

- Yeah, I think so too. It might be interesting though ... if only.

- It might, perhaps. But this isn't the right time. You need to think about your job for next year, missus. And, I know you, Angela. You are too sensitive for your own good. Besides, I can't see the principal or the staff really knowing what to do if it all blows up on Parents' Night or something. Can you?

- No, not really. Individuals would be supportive, I think, but not 'as a staff ... And the Board of Management is a bit top-heavy with Holy Joes.

$\cdots$

- Don't do it, my friend, it isn't worth it.

- Yeah, you're probably right. Not worth the grief, I suppose.

My suspicions confirmed following my conversation with K. I need to tell the girls that I won't be taking part in their movie. I write them a formal reply in keeping with the professionalism that they want for their enterprise. I give them some excuse about being camera-shy and not up for acting in a film. The next time I see them they all look crestfallen: teachers don't usually refuse to support students' projects ... and they'd asked so nicely. I suggest that there are other teachers who might be happy to take up the role.

- Ah no, Miss. We really wanted you to do it.

As I turn away, at first I feel regret at disappointing them and then I'm overwhelmed by a wave of disgust at my own hypocrisy and cowardice. I want to call them back and tell them the real reason, but I'm not even sure how I would articulate it. It's too big for me to understand myself. It's not the right time.

Denise and I discuss the story, I fill her in on Catholic schools in Ireland, what Transition Year is and so on. As we talk, some more details of the story come back to me. I remember that the girls ended up making a different film. It starred two teachers and the plot, I think, had something to do with an illicit extra-marital affair. I recall the image of Mr. G. and Mrs. N. clinking wine glasses over a candlelit dinner. Titillating in its brush with the immoral, I seem to remember that it was played for its comic value.

Later that evening back in my hotel in Bristol, I write out and think more about the story I told to Denise that morning. I think how interesting that the Transition Year girls abandoned their original story of (homophobic?) bullying. I haven't thought about this in years but as it comes back to me now I recall feeling vindicated at the time about my decision not to play along. Had it been just for the storyline, and not for the impact of Miss Rickard as THAT teacher, why wasn't another teacher offered my role? I realise that that is how I've always seen it, but I also now 
realise that I chose not to discuss it with Mrs. D.: at least I have no memory of having discussed it honestly and openly with her. Thinking back, perhaps I should have. But a lot has changed - in Ireland and in me - in the past two decades and I know I'm seeing this in a new light. It is also possible that I did try to talk to her, I really don't remember. The strongest memory of all for me in this story is the image of me placing a red rose on the coffin of a dead schoolgirl. And that never actually happened.

\section{Stories and storying}

Anyone can tell 'a simple story from [her] life'. Telling a story is easy. Irrespective of our culture, education or personal attributes we have all narrated in one way or another stories of our own and others' lives. Stories: 'these structured sequences of imagery are in fact the most natural way we know to describe almost every thing which happens in our lives' (Brooker 2004, 2). However, writing a story or narrative, and critically analysing the process involved in the 'storying' or 'narrativity' (Gubrium and Holstein 2008, 241) therein, reveals itself to be considerably more difficult. Presenting personal narrative in research and as research (DeVault 1997) adds further challenges to an already complex endeavour. We have to contend with, among other things, issues of representation, legitimation and ethics (Adams 2008; Holt 2003; Wall 2008). Accusations of narcissism and self-indulgence (Mykhalovskiy 1997; Sparkes 2002) along with dismissive rejections of so-called 'me-search' may serve to undermine and discourage the would-be auto-ethnographer.

Nevertheless, auto-ethnography is being turned to increasingly as a 'way of giving voice to personal experience to advance sociological understanding' (Wall 2008, 38). It is worth noting, as Elizabeth St-Pierre does, that auto-ethnography is not about 'individuals with experience, but subjects who are constituted through experience' (Rorty, cited St-Pierre 2008, 329). Auto-ethnographers, we are told, treat research 'as a political, socially-just and socially-conscious act' (Ellis, Adams, and Bochner 2013, 247) and using this process enables researchers to:

concentrate on ways of producing meaningful, accessible, and evocative research grounded in personal experience, research that would sensitize readers to issues of identity politics, to experiences shrouded in silence, and to forms of representation that deepen our capacity to empathize with people who are different from us. (248)

For my own part, I am attracted to this new ethnographic writing, described by Goodall (2000, 11), as 'an enlarged conversation', despite it being (or perhaps because it is) considered 'one of the most challenging qualitative approaches to attempt' (Wall 2008, 38).

Finding an appropriate story to tell from the myriad possibilities, and attempting to tell the putative 'truth', being faithful to what 'really' happened, when I have only my partial, fragmented and untrustworthy memory to guide me, only begins to scratch the surface of the difficulties that beset auto-ethnographic practice.

The partiality of, for want of a better term, the 'data' raises concerns about research reliability. While the unreliable narrator is a familiar figure in literature, she is a relative newcomer to sociological discourse. Self-consciously biased and inevitably incomplete narratives of a reconstructed past fit uneasily with the evaluation criteria of traditional research. Placing my 'self' within the frame of the research, and this is also enmeshed with the issue of reliability, brings up questions 
of vulnerability and exposure. Revealing an aspect of myself that a lifetime of uncertainty about other people's possible reactions has made prevarication and selfcensorship instinctive: can I be relied on to even notice what I am leaving out? 'Part fact, part fiction is what life is. And it is always a cover story. I wrote myself out', says Jeanette Winterson (2011, 6).

The problematic practice of auto-ethnography is further evident as treasured notions of informed consent and the safe-guarding of participants' anonymity are disrupted, to the sound of ethical alarm bells ringing, as if they were never contested issues in the first place (Walford 2005). A cursory look at the researcher's CV (or her Facebook profile) could reveal the whereabouts of her old school and erstwhile colleagues become 'known associates', particularly in a small country like Ireland.

Besides these personal and practical challenges, epistemological conundrums emerge from the manifold and shifting/shifty perspectives of stories told after a lapse of time and where different contexts and changed circumstances afford multiple interpretative vantage points. As William Tierney explains, intense moments of personal experience: "tell us something not so much about the "real" but about how individuals remember what they perceive to be the real. Peak and nadir experiences, for example, tell us, perhaps, about an actual history, but they also tell us how someone today remembers his or her past' (Tierney 1998, 62).

It is worth noting too how additionally shaky our memories of 'peak and nadir' experiences are when the filter of our heightened (or lowered) emotional state distorts and skews our perception, to the extent that we may associate inaccurately details of location, time and people to supposedly well-remembered events (Hustvedt 2010).

And Tierney (1998) continues: 'In relating these experiences, individuals help define the ideology that drives their lives and the image they have of both their own lives and of others' (62). Here Tierney notes that reality is 'the image we have', so we are always in a relationship distanced by time and space from the thing itself (Brockmeier 2000). For me, the idea that individuals 'define the ideology that drives their lives' is particularly troubling. Since exposing myself through this process to my own complicity with the oppressive and constraining ideology of the Catholic Church and the prevailing mores of Irish society in the early 1990s, like Miss Panti, I find I have to 'check myself' (O'Neill 2014). To 'check myself' also has more than one meaning: I verify and I reprimand. So I am led to question what and whose ideology determines my identity and how this works.

St-Pierre theorises that 'we only know the world and ourselves under a description' (St-Pierre 2008, 329, emphasis in original). This idea undermines any notion of the self as real. She describes her own reaction to this discovery as implying that she:

was living [her] life and producing [her]self and others (and the world) according to someone's description, and that there had been through the centuries of the past and would be through the centuries of the future other descriptions of the person, the individual, the subject... (329)

A similar idea concerning being and knowing is echoed in the evocative autoethnographic work of Carol Rambo Ronai (1999) in which she demonstrates that the creation and analysis of complex layered texts 'show how impressions from the world become internalized and layered on the existing stock of knowledge, shifting how that knowledge will affect current and future lived experience' (115). 
By writing, reading, talking, thinking, I have learned that not only is my story an 'impression from the world' but that I, myself, as depicted in this storying process, am 'under a description'. My auto-ethnographic experiment has given me fresh insights concerning my past and how social structures and available narratives colour experience. More significantly still, this process of trial (and no doubt error) has enabled me to project a future, as yet unwritten, in which more positive and less alienating experiences are imaginable ... for everyone.

\section{Response/responsibility}

In the exercise, partially described in 'Episode 1' above, my Bristol University classmate, Denise, and I exchanged stories, we took notes on our respective narratives, as instructed, and brought further insight and understanding to each other's tale. The task enabled us to encounter new layers of meaning and perspectives that were not discerned at first sight. In re-telling my narrative in these pages, as well as (just some of) the story of its development, I have consciously and deliberately re-framed it as a set of stories-within-a-story in an effort to evoke the constructed nature of narrative. I have also attempted to focus attention on particular aspects of my story and my telling of it that have appeared meaningful to me and significant in respect of broader sociological themes.

When I began thinking about the episode in question I thought about the idea of my 'self' being 'told' (or told on) by the plot of the film and the plotting (as I saw it) of the film's real mastermind. The distance of time has not made me alter my opinion of 'what was really going on' in both those sub-plots. Using an auto-ethnographic process to examine different aspects of this story, however, has caused me to trouble, and be troubled by, the working of the narrative in ways I couldn't have imagined when I began telling this 'simple story from my life'.

As I look back on the episode from school that sprang to mind, I am critical of my former self and my behaviour: I feel guilty and ashamed for what I perceive as my cowardice and hypocrisy. Even though I remind myself of the conservative social context in which I worked in the Ireland of the mid-1990s as a newly qualified teacher - it was a time when, for example, the then Archbishop of Dublin could assert confidently that homosexuality was an 'objective disorder' (Hug 2001, 22) - I can't help thinking that I missed a number of momentous opportunities. But this shift in perspective is informed by two decades of change in Irish society, in Irish schools, in attitudes towards the church as well as changes for me as I enjoy a decidedly more secure vantage point as a university lecturer these days. I know I shouldn't be so hard on my younger self.

Judith Butler writes:

As we know 'to be framed' is a complex phrase in English: a picture is framed, but so too is a criminal (by the police), or an innocent person (by someone nefarious, often the police), so that to be framed is to be set up, or to have evidence planted against one that ultimately 'proves' one's guilt ... The sense that the frame implicitly guides the interpretation has some resonance with the idea of the frame as a false accusation. If one is 'framed', then a 'frame' is constructed around one's guilty deed such that one's guilty status becomes the viewer's inevitable conclusion. Some way of organising and presenting a deed leads to an interpretive conclusion about the deed itself. (Butler 2011, 8) 
When I was approached by the Transition Year girls with their nicely worded letter, as my version of the story has it, I felt set up in precisely the way Butler describes. Not by the girls, but by my art teacher colleague, although I would use the adjective 'mischievous' rather than 'nefarious'. Paradoxically, if the set-up really were intended to suggest a theme of unspoken lesbianism, then I would have to plead 'guilty as charged'. This is exactly what determined my refusal to take part in the film. I can't help being struck now by the irony: a fictitious story that sets out to reveal 'the truth' is rejected to protect a 'fiction' I was trying to maintain in 'real' life! I am writing my self out.

And context determined the imagined response of my colleagues. Compassionate and undoubtedly 'tolerant' though they may have been, many heterosexual teachers and school principals were simply ignorant of the experiences of their lesbian or gay colleagues and the multifarious ways even ordinary everyday conversation constrained and silenced us (Epstein 1994; Rogers 1994) and, by all accounts, still do (Gamble 2014). Desirous of a quiet life, albeit inevitably also a double one, many of us would have found it difficult to imagine voicing resistance to the dominant narrative of heteronormativity in schools (Gowran 2004). In the context of this benign silence, my defence concerning my complicity in maintaining a heterosexist social order, and my reticence to fly the flag for equality, is that at the time I could see no viable alternative narrative for me. And even if I did rail against the pronouncements of the pope and the archbishop among my friends at the weekend, being a lesbian teacher in a convent school somehow felt 'wrong'. Trying to convince others otherwise, without first confronting my own ambivalence about it, was literally un-thinkable.

Reflecting further on the story, more grounds for self-reproach emerge as the prosecutor from my courtroom of conscience adds to the initial charge of non-solidarity with oppressed LGBT (Lesbian, Gay, Bisexual and Transgender) colleagues of yesteryear. She hits me with the additional indictment of dereliction of my professional duty of care for teenagers struggling to come to terms with their sexual orientation at a difficult and vulnerable time in their lives (O'Carroll and Szalacha 2000). ... This short film project, my learned friends, provided the accused with an ideal opportunity to epitomise the role of a teacher sympathetic towards diversity, whom pupils, especially those experiencing the trauma of homophobic bullying, might have been able to identify with and turn to. Alas no! She chose instead to leave them to their own devices on the grounds that it wasn $\mathrm{t}$ the right time.

And what is my response to that? ... Yes, your honour, I have found myself wanting. That is to say, I have found myself craving a different end to the story to make good the shortcomings unearthed during my troubling self-interrogation.

Social context and dominant narratives can be blamed for inaction and for the constraints and limitations it puts on the imagination: my own and that of others. I can re-visit my earlier self and forgive my complicity, reticence and hypocrisy. But further cross-examination reveals perhaps more damning evidence for the present time. In re-telling a story, however faithfully re-membered or honestly and reflexively presented, there is no escaping the fact that my story implicates others. And one colleague in particular is treated in my story as a mischievous and scheming colleague (with reference to me and indeed of the pupils). The portrayal is less than favourable and my account leaves her with no right to reply. Social context explains a lot but so does personal agency and choice. So what to do about this characterisation when from my perspective it is accurate? Like Tony Adams, cited by Sikes 
(2013), I can claim the privilege of limited readership for this academic article. Is it enough then to just be 'aware of this control [over our portrayal] ... when we write about others' (Adams 2008, cited Sikes 2013, 62)? Sikes also provides scant comfort by suggesting that critical friends can 'give us their impressions of what we have written' (62). Even though I favour that approach very much, and do it all the time, what if, as I come to the end of this process of writing, reading, thinking and talking, my essay fails to pass ethical muster? What if I am found to have abused my narrative power 'to demean, belittle or take revenge' (Sikes 2013, 62)? Although I believe that my conscience is clear, and indeed I have revised and softened the portrayal of Mrs. D. following readings on ethics in narrative process (Josselson 1996; Sikes 2013), I am still uneasy about the inevitability for future projects that in the 'telling of tales out of school' our personal narratives risk causing offence or harm to others regardless of our mitigating actions.

\section{Concluding remarks}

To draw a final image for this article I would like to project a different scenario for the reader: it is of a heroic, tech-savvy young English teacher, proudly, albeit discreetly, sporting her rainbow colours. She and her colleagues develop their students' digital literacy as together they come up with powerful, positive messages of solidarity with young LGBT people. My fantasy movie also features empowered selfassured LGBT teenagers. The audience gets an impression of confidence and selfassurance as staff and students all work together in a context of collaboration and mutual support. Although this also hasn't happened yet and Section 37.1 is still enshrined in the Employment Equality Act, ${ }^{1}$ the diminished power of the Catholic Church, greater diversity in Ireland, the success of progressive campaigns for change by my more courageous peers (Lodge et al. 2007; O'Carroll and Szalacha 2000), and more visible and widely articulated positive images of LGBT lives provided by new heralds of our age such as the Irish National Teachers Organisation's LGBT group (Gamble 2014), Miss Panti Bliss (O'Neill 2014), as well as LGBT and straight activists, politicians, broadcasters, writers, educators and others who speak out about homophobia, all make me feel optimistic that one day it could.

Episode 2

A short film where the narrator looks forward in time and finds what she wants

\section{FADE IN}

[Wide-angle shot. Modern classroom. A teacher works at a computer. Four teenage girls enter from the right. The teacher looks up and smiles.]

Clodagh: Hi Miss Rickard. Sorry to interrupt! Have you read our script? Did you like it?

Miss Rickard: Hi girls! I have, Clodagh and I did. Even if you have typecast me!

Clodagh: Ah Miss! It's not like that! We really think you'd be brilliant! Will you do it?

Miss Rickard: No I'm only joking about that. I'd be happy to do it. Just that, well, I do have one issue with it

[The girls look puzzled.] 
Miss Rickard: What? You can't guess what it is?

Clodagh: Is it 'cos it hints that the girl has a crush on you?

Miss Rickard: No, it's not that. That's kinda the point isn't it?

Clodagh: Well ... yeah, that's right. So what didn't you like?

Miss Rickard: Girls, honestly, it's too sad! That last scene ... the graveyard? The rose? You should know that suicide isn't the answer, I'm surprised Mrs. D. even let you away with that!

Clodagh: Yeah well, actually she hasn't seen the script yet! We were just so excited and wanted you to read it.

Miss Rickard: Is that right? Well, if you come up with a more hopeful message I'll take part. We should do a lesson for English on how homosexuality is portrayed in literature. When you see that, it might stop you killing off the LGBT characters in your own productions!

FADE OUT

Note

1. The Employment Equality Act $(1998,2004)$ states: 'A religious, educational or medical institution which is under the direction or control of a body established for religious purposes or whose objectives include the provision of services in an environment which promotes certain religious values shall not be taken to discriminate against a person for the purposes of this Part or Part II if $-a$ ) it gives more favourable treatment, on the religion ground, to an employee or a prospective employee over that person where it is reasonable to do so in order to maintain the religious ethos of the institution, or b) it takes action which is reasonably necessary to prevent an employee or a prospective employee from undermining the religious ethos of the institution.'

\section{Notes on contributor}

Angela Rickard is a lecturer in the Education Department at Maynooth University and a doctoral student in the Graduate School of Education at the University of Bristol.

\section{References}

Adams, T. E. 2008. “A Review of Narrative Ethics.” Qualitative Inquiry 14 (2): 175-194.

Brockmeier, J. 2000. “Autobiographical Time.” Narrative Inquiry 10 (1): 51-73.

Brooker, C. 2004. The Seven Basic Plots: Why We Tell Stories. London: Bloomsbury.

Butler, J. 2011. Frames of War: When is a Life Grievable? London: Verso.

DeVault, M. J. 1997. "Personal Writing in Social Research." In Reflexivity and Voice, edited by R. Hertz, 216-228. Thousand Oaks, CA: Sage.

Ellis, C., T. Adams, and A. P. Bochner. 2013. "Autoethnography: An Overview." In Autoethnography, edited by P. Sikes, vol. II, 247-264. London: Sage.

Epstein, D., ed. 1994. Challenging Lesbian and Gay Inequalities in Education. Buckingham: Open University Press.

Gamble, E. 2014. "Straight-talking Staffrooms" (blogpost). Accessed May 30. http://notasec ond-classteacher.com

Goodall, H. L. 2000. Writing the New Ethnography. Lanham: Alta Mira Press.

Gowran, S. 2004. “'See No Evil, Speak No Evil, Hear No Evil?' the Experiences of Lesbian and Gay Teachers in Irish Schools." In Primary Voices, Equality, Diversity and Childhood in Irish Primary Schools, edited by J. Deegan, D. Devine and A. Lodge, 37-55. Dublin: IPA. 
Gubrium, J. F., and J. A. Holstein. 2008. "Narrative Ethnography." In Handbook of Emergent Methods, edited by S. N. Hesse-Biber and P. Leavy, 241-264. London: The Guilford Press.

Holt, N. L. 2003. "Representation, Legitimation and Autoethnography: An Autoethnographic Writing Story." International Journal of Qualitative Methods 2 (1): 18-28.

Hug, C. 2001. "Moral Order and the Liberal Agenda in the Republic of Ireland." New Hibernia Review 5 (4): 22-41.

Hustvedt, S. 2010. The Shaking Woman or a History of My Nerves. London: Picador.

Josselson, R. 1996. Ethics and Process in the Narrative Study of Lives. Thousand Oaks, CA: Sage.

Lodge, A., S. Gowran, and K. O'Shea. 2007. Valuing Visibility: An Exploration of How Issues of Sexual Orientation Arise and Are Addressed in Post-primary Schools. Dublin: Jointly Published by Department of Education and Science, Gay and Lesbian Equality Network and National University of Ireland, Maynooth.

Mykhalovskiy, E. 1997. "Reconsidering Table Talk: Critical Thoughts on the Relationship Between Sociology, Autobiography and Self-Indulgence." In Reflexivity and Voice, edited by R. Hertz, 229-251. Thousand Oaks, CA: Sage.

O'Carroll, I. B., and L. Szalacha. 2000. A Queer Quandary: The Challenges of Including Sexual Difference within the Relationships and Sexuality Education Programme. Dublin: LEA/LOT.

O' Neill, R. 2014. "Panti's Nobel Call at That Abbey Theatre" (video). http://www.youtube. $\mathrm{com} /$ watch?v $=$ WXayhUzWnl0

Rambo Ronai, C. 1999. "The Next Night Sous Rature: Wrestling with Derrida's Mimesis." Qualitative Inquiry 5 (1): 114-129.

Rogers, M. 1994. "Growing Up Lesbian: The Role of the School." In Challenging Lesbian and Gay Inequalities in Education, edited by D. Epstein, 31-48. Buckingham: Open University Press.

Sikes, P. 2013. "The Ethics of Writing Life Histories and Narratives in Educational Research." In Autoethnography, edited by P. Sikes, vol. III, 57-70. London: Sage.

Sparkes, A. 2002. “Auto-ethnography: Self Indulgence or Something More?" In Ethnographically Speaking: Autoethnography, Literature, and Aesthetics, edited by A. P. Boucher and C. Ellis, 209-232. Walnut Creek, CA: Alta Mira.

St-Pierre, E. 2008. "Decentering Voice in Qualitative Inquiry." International Review of Qualitative Research 1 (3): 319-336.

Tierney, W. G. 1998. "Life History's History: Subjects Foretold." Qualitative Inquiry 4 (1): 40-70.

Walford, G. 2005. "Research Ethical Guidelines and Anonymity." International Journal of Research and Method in Education 28 (1): 83-93.

Wall, S. 2008. "Easier Said than Done: Writing an Autoethnography." International Journal of Qualitative Methods 7 (1): 38-53.

Winterson, J. 2011. Why Be Happy When You Could Be Normal? London: Jonathan Cape. 